\title{
STUDI KASUS PEMENUHAN KEBUTUHAN OKSIGENASI DENGAN TEKNIK RELAKSASI NAFAS DALAM PADA PASIEN CONGESTIVE HEART FAILURE DI RUMAH SAKIT TK II PUTRI HIJAU MEDAN TAHUN 2016
}

\section{Case Study Of Fulfillment Of Oxygenation Needs With In-Relaxation Relaxation Technique In Congestive Heart Failure Patients at the Putri Hijau Hospital II Medan in 2016}

\author{
Lermiana Purba ${ }^{1}$, Deni Susyanti ${ }^{2}$, Pamungkas ${ }^{3}$ \\ ${ }^{1,2}$ Dosen Tetap Yayasan Akper Kesdam I/BB Medan \\ ${ }^{3}$ Mahasiswa Akper Kesdam I/BB Medan \\ E-mail: deni_susyanti@yahoo.co.id
}

\begin{abstract}
Abstrak
Congestive Heart Failure ketidakmampuan jantung memompakan darah yang adekuat untuk memenuhi kebutuhan jaringan akan oksigen dan nutrisi menyebabkan curah jantung menurun sehingga menimbulkan nyeri dada. Managemen nyeri dapat dilakukan dengan farmakologi dan nonfarmakologi. Managemen nyeri keperawatan nonfarmakologi yaitu dengan teknik relaksasi nafas dalam. Pemberian teknik relaksasi nafas dalam akan meningkatkan suplai oksigen ke jaringan sehingga menurunkan tingkat nyeri yang dialami individu. Metode penelitian ini merupakan penelitian deskriptif dengan rancangan studi kasus yang bertujuan untuk mengetahui gambaran studi kasus pemenuhan kebutuhan oksigenasi dengan teknik relaksasi nafas dalam pada pasien Congestive Heart Failure. Pendekatan proses keperawatan yang dilakukan peneliti meliputi tahapan pengkajian, diagnose, intervensi, implementasi dan evaluasi keperawatan pada 2 klien dengan kasus yang sama. Hasil pada evaluasi kedua kasus didapatkan hasil bahwa pada kasus I sudah tidak ada nyeri dada pada hari ke 3 perawatan. Sedangkan pada kasus II keluhan sesak sudah teratasi pada hari ke 3 dibuktikan dengan klien tampak tenang. Kesimpulan yang didapatkan dalam pemenuhan kebutuhan oksigenasi adalah mengalami peningkatan dalam mengatasi kebutuhan oksigenasi dengan teknik relaksasi nafas dalam. Saran dilanjutkan kepada klien dan keluarga agar selalu memperhatikan program pengobatan secara rutin dan melakukan teknik relaksasi nafas dalam.
\end{abstract}

Kata kunci : Congestive Heart Failure $(\mathrm{CHF})$, Pemenuhan Kebutuhan Oksigenasi, Teknik Relaksasi Nafas Dalam

\begin{abstract}
Congestive heart failure is the incapacity of heart to pump adequate blood in fulfilling the need for oxygen ad nutrients which causes cardiac output to decrease which brings about pain in chest. Pain management can be done by using pharmacological and non-pharmacological therapies. Deep breath relaxation therapy is done in the nonpharmacological nursing pain management. It will increase the supply of oxygen to tissues so that pain will decrease. The research used descriptive method with case study design which was aimed to find out the description of the need for oxygen in congestive heart failure patients. The nursing approach consisted of nursing analysis, diagnosis, intervention, implementation, and evaluation in 2 clients with the same case. The result showed that in case I there was no more pain in chest in the third day of nursing, while in case II complaint about short of breath could be handled in the third day of nursing since the client felt relaxed. The conclusion was that the need for oxygen could be handled by using deep breath relaxation technique. It is recommended that the clients and their families comply with doing deep breath relaxation technique.
\end{abstract}

Keywords: Congestive Heart Failure (CHF), Fulfillment Of Oxygenation needs, Deep Breath Relaxation Technique

\section{PENDAHULUAN}

Congestive Heart Failure adalah ketidakmampuan jantung untuk memompakan darah yang adekuat untuk memenuhi kebutuhan jaringan akan oksigen dan nutrisi (Kasron,2016).Congestive Heart Failure mengakibatkan kegagalan fungsi pulmonal sehingga terjadi penimbunan cairan di alveoli, hal ini menyebabkan jantung tidak dapat berfungsi dengan maksimal dalam memompa darah. Dampak lain yang muncul adalah perubahan yang terjadi pada otot-otot respiratori sehingga hal tersebut dapat mengakibatkan suplai oksigen ke seluruh tubuh terganggu sehingga terjadinya dispnea. Perawat sebagai pemberi asuhan keperawatan melalui tindakan mandiri dan kolaboratif memfasilitasi pasien untuk menyelesaikan masalah. Penatalaksanaan non farmakologi yang dapat dilakukan yaitu edukasi, latihan dan 
peningkatan kapasitas fungsional (Nirmalasari, 2015).

Gejala utama pasien gagal jantung yaitu nyeri dada. Nyeri dada timbul secara mendadak. Menyebabkan yaitu suplai oksigen ke miokardium mengalami penurunan yang berakibat kematian sel jantung. Gejala klinis nyeri dada pada kasus gagal jantung, muncul secara tiba-tiba dan secara terus menerus serta tidak merada. Apabila nyeri ini dibiarkan, tingkat keparahan nyeri akan menjadi meningkat sehingga nyeri tidak tertahankan, tingkat keparahan nyeri akan menjadi meningkat sehingga nyeri tidak tertahankan lagi. Nyeri tersebut dapat menjalar ke leher, bahu dan terus menuju lengan (Aspian, 2014)

Gagal jantung menyebabkan curah jantung menurun, menyebabkan hipertrofi ventrikel, pemendekan miokard, pengisian LV menurun, aliran tidak adekuat ke jantung dan otak, menyebabkan risiko tinggi penurun curah jantung, kemudian penurunan suplai $\mathrm{O} 2$ ke miokard, terjadi peningkatan hipoksia jaringan miokardium, dan menyebabkan perubahan metabolisme miokardium sehingga menimbulkan nyeri dada (muttaqin, 2014)

Seorang mengalami nyeri akan dampak pada aktivitas sehari - hari. Selain itu, seorang mengalami nyeri hebat dan nyerinya bekelajutan, apabila tidak segera ditangani pada akhirnya dapat mengakibatkan syok neurologik pada seorang tersebut (Agung, Andriyani, \& Sari, 2013). Selanjutnya untuk mencegah hal tersebut perlu dilakukan managemen nyeri.

Managemen nyeri adalah bagian dari displin aatau pain relif (Prarintya, Harmilah, \& Subroto, 2014). Beberapa managemen nyeri keperawatan terapi non farmakologis diantaranya seperti mengatur posisi fisiologis dan mobilisasi ekstremitas yang mengalami nyeri, menginstirahatkan klin, manajemen lingkungan, teknik relaksasi nafas dalam, (Muttaqin, 2014)

Pemberian teknik relaksasi nafas dalam akan meningkatkan suplai oksigen ke jaringan sehingga menurunkan tingkat nyeri yang dialami individu (Agung, Andriani, \& Sari, 21013)

Latihan nafas diafragmatik adalah tindakan non farmakologi pada pasien gagal jantung yang dapat meningkatkan saturasi oksigen dan menurunkan dispnea. Latihan nafas diafragmatik ini dilakukan 30 menit per hari selama 14 hari. Hasil dari latihan nafas diafragmatik menunjukan adanya penurunan pada dispnea dengan hasil $\mathrm{p}=0,000$, alfa $=0,05$ (jurnal sepdianto, 2013)

Penyakit jantung dan pembuluh darah merupakan salah satu masalah kesehatan utama di negara maju maupun berkembang. Penyakit gagal jantung menjadi penyebab nomor satu kematian di dunia dengan di perkirakan akan terus meningkat hingga mencapai 23,3 juta pada tahun 2013 (Yancy, 2013)

Menurut data kesehatan dunia world health organization (2015) penyakit gagal jantung merupakan penyakit yang dapat menyebabkan kematian. Sekitar 5,1 juta orang di amerika serikat mengalami gagal jantung. Sekitar setengah dari orang-orang yang menderita gagal jantung meninggal dalam waktu 5 tahun setelah didiagnosis (Center for Disease Control and Prevention, 2015)

Di indonesia prevalensi penyakit gagal jantung tahun 2013 sebesar $0,13 \%$ atau diperkirakan sekitar 229.696 orang. Jumlah penderita terbanyak berdasarkan diagnosis dokter terdapat di provinsi jawa timur sebanyak 54.826 orang $(0,19 \%)$, sedangkan jumlah penderita paling sedikit ditemukan di provinsi Maluku yaitu sebanyak 144 orang $(0,02 \%)$. Di provinsi daerah istimewa sumatra utara berdasar diagnosis/gejala, estimitas jumlah penderita gagal jantung sebanyak 26.819 orang $(0,3 \%)$ (RISKESDAS, 2014)

Berdasarkan data medical record di rumah sakit TK II Putri Hijau Medan dijumpai pasien rawat inap dengan diagnosa Congestive Heart Failure pada bulan januari s/d Oktober tahun 2016 sekitar 181 orang pasien.

Dari fenomena diatas penulis tertarik untuk meneliti tentang Studi Kasus pemenuhan Kebutuhan Oksigenasi dengan Teknik Relaksasi Nafas Dalam Terhadap Dispnea pada pasien Congestive Heart Failure do rumah sakit TK II Putri Hijau Medan Tahun 2016. 


\section{METODE}

Penelitian ini merupakan penelitian deskriptif dengan rancangan studi kasus pemenuhan kebutuhan nutrisi pada pasien PPOK dengan menggunakan pendekatan proses keperawatan yang dilakukan peneliti. Subyek penelitian yang digunakana adalah 2 pasien dengan 1 kasus dengan masalah keperawatan yang sama. Studi kasus berjudul Pemenuhan Kebutuhan Nutrisi Pada Pasien PPOK dengan kriteria inklusi: bersedia menjadi subjek penelitian, pasien PPOK, Usia (40 Tahun ke atas), dengan pemenuhan kebutuhan nutrisi. Kriteria eksklusi: pasien menolak penelitian, memiliki komplikasi yaitu insufisiensi pernapasan, gagal napas, pneumonia, atelektasis, pneumothoraks. Fokus studi dalam penelitian ini yaitu pemenuhan kebutuhan nutrisi pada pasien PPOK dengan dua pasien dalam kasus yang sama. Laporan ini penulis membatasi pada Asuhan Keperawatan Medikal Bedah dengan Gangguan Sistem Pernapasan PPOK di Rumah Sakit Putri Hijau TK II Medan lama sejak pasien pertama kali masuk rumah sakit sampai pulang dan atau yang dirawat minimal 4 hari. Penelitian akan dilakukan pada bulan Nopember 2016.

Alat atau instrument pengumpulan data dalam wawancara menggunakan format pengkajian asuhan keperawatan medikal bedah sedangkan dalam observasi menggunakan alat-alat seperti tensimeter, stetoskop, dan timbangan. Metode Pengumpulan data dalam karya tulis studi kasus ini adalah dengan menggunakan instrument Biofisiologis, Observasi, Wawancara, Kuesioner, dan Skala penilaian.

\section{HASIL}

Pengkajian

a. Identitas dan Hasil Anamnesa

Pengkajian

a. Identitas dan hasil anamnesa

Tabel 1. Identitas pasien dan hasil anamnesa

\begin{tabular}{clcc}
\hline No & $\begin{array}{c}\text { Identitas } \\
\text { Pasien }\end{array}$ & Kasus I & Kasus II \\
\hline 1 & $\begin{array}{l}\text { Diagnosa } \\
\text { medis }\end{array}$ & $\begin{array}{c}\text { Congestive } \\
\text { Heart Failure }\end{array}$ & $\begin{array}{c}\text { Congestive } \\
\text { Heart } \\
\text { Failure } \\
\end{array}$ \\
& Nama & Tn.H & Ny.K \\
\hline
\end{tabular}

2.

3. Umur 58 Tahun 50 Tahun

4. Jenis Laki-laki Perempuan

Kelamin

5. Pendidika Tamat SMA SD $n$

6. Pekerjaan Wira Swasta Ibu rumah

7. Status Menikah Menikah

8. Agama Islam Islam

9. Suku/Ban Batak/Indon Jawa/Indon gsa esia esi

10. Bahasa Indonesia Indonesia

11. Alamat Desa Batu J1 Krakatau $\begin{array}{ll}\text { bolak } & \text { Medan } \\ \text { BPJS } & \text { BPJS }\end{array}$ ng oleh

13. Tanggal $10 \quad 12$ dan jam Nopember Nopem Masuk 2016 Pukul ber rumah $\quad 07.00 \mathrm{wib} \quad 2016$ sakit Pukul 21.00 wib

14. Tanggal $10 \quad 12$

\begin{tabular}{lcc} 
dan jam & Nopember & Nopem \\
pengkajia & 2016 Pukul & ber \\
n & 09.00 wib & 2016 \\
& & Pukul \\
& & 22.00 \\
& & wib \\
\hline
\end{tabular}

Berdasarkan tabel diatas didapatkan 2 responden mempunyai diagnosa medis yang sama yaitu Congestive Heart Failure. Pada kasus I berpendidikan Tamatan SMA dan suku Batak sedangkan pada kasus II berpendidikan SD dan suku Jawa.

Pemeriksaan fisik kedua responden dimulai dari Breath (B1), kedua responden memiliki bentuk dada simetris. Pada kedua kasus pergerakan pernafasan thorakal abdominal. Pada kasus I dan II memiliki frekuensi yakni pada kasus I sebanyak $32 \mathrm{x} /$ menit dan pada kasus II sebanyak $30 \mathrm{x} /$ menit. Pada kasus 1 dan II mengalami nyeri dada.

Pemeriksaan fisik pada Blood (B2), pada kedua responden memiliki perbedaan tekanan darah dan nadi. Pada kasus I tekanan darah 140/ $80 \mathrm{mmHg}$, nadi $80 \mathrm{x} /$ 
menit sedangkan kasus II tekanan darah 160/ $80 \mathrm{mmHg}$, nadi $88 \mathrm{x} / \mathrm{menit}$ Kedua responden memiliki Capillary Refill Time < 2 detik, suara jantung tambahan (murmur/bising), akral pada kedua hangat. Pada kasus 1 terdapat chest pain pada sebelah kiri, sedangkan kasus 2 tidak ada.

Pemeriksaan fisik pada Brain (B3),

kedua responden memiliki kesadaran compos mentis dengan GCS 45 6. Pada kedua responden tidak ada gangguan saraf carnial dan fungsi motorik, fungsi sensorik dalam batas normal. Kedua responden memiliki memori yang dapat meningat jangka panjang dan pendek.

Pemeriksaan fisik pada Bowel dan Reproduksi (B5), pada kasus I dan kasus II terdapat Bentuk abdomen simetris, peristaltic usus $8 \mathrm{x} / \mathrm{i}$, tidak ada massa tumor, tidak ada asites hepar dan limfa tidak ada pembesaran.

Pemeriksaan fisik pada Bone dan Muskuskeletal (B6), kedua responden memiliki kekuatan otot yang sama

Ekstremitas sup dex 5 Ekstermitas sup sin 5 Ekstermitas inf dex 4 Ekstermitas sup $\sin 4$, tidak ada kekakuan dan kontraktur pada kedua responden, tidak ada spastic dan flasit pada kedua responden. Pola latihan gerak pada kedua responden dapat digerakan dengan aktif. Kasus I dan kasus II memiliki suhu tubuh $37^{\circ} \mathrm{C}$. Kedua

b. Pemeriksaan diagnostik

Tabel 2. Pemeriksaan Diagnostic

\begin{tabular}{|c|c|c|c|c|}
\hline \multirow{2}{*}{$\begin{array}{c}\text { Jenis } \\
\text { Pemeriksa } \\
\text { an }\end{array}$} & \multicolumn{2}{|c|}{ Hasil } & \multirow[b]{2}{*}{$\begin{array}{c}\text { Satu } \\
\text { an }\end{array}$} & \multirow{2}{*}{$\begin{array}{l}\text { Nilai } \\
\text { Ruju } \\
\text { kan }\end{array}$} \\
\hline & $\begin{array}{c}\text { Kasus } \\
\text { I }\end{array}$ & $\begin{array}{c}\text { Kasus } \\
\text { II }\end{array}$ & & \\
\hline $\begin{array}{l}\text { Laboratori } \\
\text { um }\end{array}$ & $\begin{array}{c}\text { Tangg } \\
\text { al }\end{array}$ & $\begin{array}{c}\text { Tangga } \\
1\end{array}$ & & \\
\hline Darah & periksa & periksa & $g / d L$ & L:13- \\
\hline Rutin & 10 & 12 & $\%$ & 16 \\
\hline $\begin{array}{l}\text { a. Hemogl } \\
\text { obin }\end{array}$ & $\begin{array}{l}\text { Nope } \\
\text { mber }\end{array}$ & $\begin{array}{c}\text { Nopem } \\
\text { ber }\end{array}$ & $\begin{array}{l}/ \mu \\
/ \mu \mathrm{L}\end{array}$ & $\begin{array}{l}\mathrm{P}: 12- \\
14\end{array}$ \\
\hline b. Hemato & 2016 & 2016 & & L:40- \\
\hline krit & 15,5 & 12,9 & $\mathrm{mg} / \mathrm{d}$ & 48 \\
\hline c. Leukosit & 44,8 & 34,7 & $\mathrm{~L}$ & P:37- \\
\hline d. Trombos & 9000 & 895 & $\mathrm{mg} / \mathrm{d}$ & 43 \\
\hline it & 269.00 & 0 & $\mathrm{~L}$ & 5- \\
\hline e. Bilirubin & 0 & 320. & $\mathrm{u} / \mathrm{L}$ & $10.10^{3}$ \\
\hline Total & & 800 & $\mathrm{u} /$ & $/ \mu \mathrm{L}$ \\
\hline Direk & 0,89 & & $\mathrm{mg} / \mathrm{d}$ & $150-$ \\
\hline f. SGOT & 0,60 & 0,58 & $\mathrm{~L}$ & 400.1 \\
\hline
\end{tabular}

\begin{tabular}{lcccl}
\hline g. SPGT & 67 & 0,22 & $\mathrm{mg} / \mathrm{d}$ & $0^{3}$ \\
h. Choleste & 134 & 13 & $\mathrm{~L}$ & \\
rol total & 129 & 8 & $\mathrm{mg} / \mathrm{d}$ & $<1$ \\
i. HDL & 35 & 104 & $\mathrm{~L}$ & $<0,3$ \\
Choleste & 60 & 50 & $\mathrm{mg} / \mathrm{d}$ & $\mathrm{L}:<35$ \\
rol & 168 & 260 & $\mathrm{~L}$ & $\mathrm{P}:<31$ \\
j. LDL & 29 & 56 & $\mathrm{mg} / \mathrm{d}$ & $\mathrm{L}:<45$ \\
$\quad$ Choleste & 1,2 & 26 & $\mathrm{~L}$ & $\mathrm{P}:<34$ \\
$\quad$ rol & & 1,3 & $\mathrm{mg} / \mathrm{d}$ & $<200$ \\
k. Trigliser & 8,6 & & $\mathrm{~L}$ & $>40$ \\
ida & 124 & 5,8 & & $<100$ \\
1. Ureum & 146 & & $\mathrm{mg} / \mathrm{d}$ & $<150$ \\
m. Kreatini & 3,3 & 139 & $\mathrm{~L}$ & $<50$ \\
n & 102 & 4,4 & & $\mathrm{~L}: 0,8-$ \\
n. Asam & & 110 & $\mathrm{mmo}$ & 1,3 \\
urat & & & $1 / \mathrm{L}$ & $\mathrm{P}: 0,6-$ \\
o. Glukosa & & & $\mathrm{mmo}$ & 1,2 \\
puasa & & & $1 / \mathrm{L}$ & $\mathrm{L}:<7$ \\
p. Natrium & & & $\mathrm{mmo}$ & $\mathrm{P}:<5$, \\
q. Kalium & & & $1 / \mathrm{L}$ & 7 \\
r. Klorida & & & & \\
\hline
\end{tabular}

Berdasarkan tabel di atas didapatkan dari kedua responden sama sama dilakukan pemeriksaan laboratorium yaitu pemeriksaan darah rutin.

c. Analisa data

Dari hasil analisa data dapat disimpulkan bahwa pasien I mengalami masalah penurunan curah jantung berhubungan dengan kontraktilitas ventrikel kiri ditandai dengan Klien mengatakan sesak dan nyeri dada sedangkan kasus II klien mengatakan sesak nafas. Pemenuhan kebutuhan oksigenasi dibantu dengan teknik relaksasi nafas dalam.

\section{d. Diagnosa Keperawatan}

Dari kedua responden mempunai masalah Penurunan curah jantung berhubungan dengan kontraktilitas ventrikel kiri menyebabkan peregangan otot jantung ditandai dengan klien mengatakan sesak dan nyeri dada.

e. Rencana Keperawatan

\section{Tabel 3. Rencana Keperawatan}

\section{Intervensi}

1. Evaluasi episode nyeri dada (intensitas lokasi, radiasi, durasi dan factor yang memicu serta meringankan nyeri dada.

$\mathrm{R} /$ Nyeri dan penurunan curah jantung dapat merangsang sistenm saraf simpatis untuk mengeluarkan sejumlah besar norevinefrin. 
2. Monitoring tanda-tanda vital secara rutin.

$\mathrm{R} /$ Pada CHF dini, sedang atau kronis TD dapat meningkat sehubungan dengan SVR pada CHF lanjut tubuh tidak mampu lagi mengkonpensasi dan hipotensi tidak dapat normal lagi.

3. Catat tanda dan gejala penurunan curah jantung.

$\mathrm{R} /$ penurunan curah jantung dapat menunjukkan menurunnya nadi radial, popliteal, odrsalis pedis, dan postibial. Nadi mungkin cepat hilang atau tidak teratur untuk di palpasi, dan pulsus alternan (denyut kuat lain dengan denyut lemah) mungkin ada.

4. Monitor status pernafasan terkait dengan adanya gejala gagal jantung.

R/ kelebihan volume cairan sering menimbulkan kongesti paru . gejala edema paru dapat menunjukkan gagal jantung kiri akut. Gejala pernafasan pada gagal jantung kanan (dipsnea.batuk, ortopnea) dapat timbul lambat tetapi lebih sulit membaik.

5. Evaluasi perubahan tekanan darah.

$\mathrm{R} /$ pada CHF dini, sedang atau kronis TD dapat meningkat sehubungan dengan SVR pada CHF lanjut tubuh tidak mampu lagi mengkonpensasi dan hipotensi tidak dapat normal lagi.

6. Susun waktu latihan dan istirahat mencegah kelelahan.

$\mathrm{R} /$ istirahat fisik harus dipertahankan selama CHF akut atau refraktori untuk memperbaiki efisiensi kontraksi jantung dan menurunkan kebutuhan/konsumsi oksigen miokard dan kerja berlebihan.

7. Monitoring toleransi aktivitas pasien.

$\mathrm{R} /$ Dapat menunjukan peningkatan dekompensasi jantung dari pada kelebihan aktivitas.

8. Monitor sesak nafas, kelelahan takipnea, dan orthopnea.

R/ kelebihan volume cairan sering menimbulkan kongesti paru . gejala edema paru dapat menunjukkan gagal jantung kiri akut. Gejala pernafasan pada gagal jantung kanan (dipsnea.batuk, ortopnea) dapat timbul lambat tetapi lebih sulit membaik.

9. Berikan dukungan teknik yang efektif untuk mengurangi stress.

$\mathrm{R} /$ stress emosi menghasilkan vasokontriksi, yang meningkatkan TD dan meningkatkan frekuensi atau kerja jantung.

10.Lakukan terapi relaksasi nafas dalam.

$\mathrm{R} /$ meningkatkan suplai oksigen sehingga nyeri dapat berkurang.

11.Instruksikan pasien dan keluarga mengenai tujuan perawatan dan bagaimana kemajuan akan diukur.

\begin{abstract}
R/ Pengetahuan proses penyakit dan harapan dapat memudahkan ketaatan pada program pengobatan
\end{abstract}

1. Evaluasi episode nyeri dada (intensitas lokasi, radiasi, durasi dan factor yang memicu serta meringankan nyeri dada.

R/ Nyeri dan penurunan curah jantung dapat merangsang sistenm saraf simpatis untuk mengeluarkan sejumlah besar norevinefrin.

2. Monitoring tanda-tanda vital secara rutin. $\mathrm{R} /$ pada CHF dini, sedang atau kronis TD dapat meningkat sehubungan dengan SVR pada CHF lanjut tubuh tidak mampu lagi mengkonpensasi dan hipotensi tidak dapat normal lagi.

3. Catat tanda dan gejala penurunan curah jantung.

$\mathrm{R} /$ penurunan curah jantung dapat menunjukkan menurunnya nadi radial, popliteal, odrsalis pedis, dan postibial. Nadi mungkin cepat hilang atau tidak teratur untuk di palpasi, dan pulsus alternan (denyut kuat lain dengan denyut lemah) mungkin ada.

4. Monitor status pernafasan terkait dengan adanya gejala gagal jantung.

$\mathrm{R} /$ kelebihan volume cairan sering menimbulkan kongesti paru . gejala edema paru dapat menunjukkan gagal jantung kiri akut. Gejala pernafasan pada gagal jantung kanan (dipsnea.batuk, ortopnea) dapat timbul lambat tetapi lebih sulit membaik.

5. Evaluasi perubahan tekanan darah.

$\mathrm{R} /$ pada CHF dini, sedang atau kronis TD dapat meningkat sehubungan dengan SVR pada CHF lanjut tubuh tidak mampu lagi mengkonpensasi dan hipotensi tidak dapat normal lagi.

6. Susun waktu latihan dan istirahat mencegah kelelahan.

$\mathrm{R} /$ istirahat fisik harus dipertahankan selama CHF akut atau refraktori untuk memperbaiki efisiensi kontraksi jantung dan menurunkan kebutuhan/konsumsi oksigen miokard dan kerja berlebihan.

7. Monitoring toleransi aktivitas pasien.

$\mathrm{R} /$ dapat menunjukan peningkatan dekompensasi jantung dari pada kelebihan aktivitas.

8. Monitor sesak nafas, kelelahan takipnea, dan orthopnea.

$\mathrm{R} /$ kelebihan volume cairan sering menimbulkan kongesti paru . gejala edema paru dapat menunjukkan gagal jantung kiri akut. Gejala pernafasan pada gagal jantung kanan (dipsnea.batuk, ortopnea) dapat timbul lambat tetapi lebih sulit membaik. 
9. Berikan dukungan teknik yang efektif untuk mengurangi stress.

$\mathrm{R} /$ Stress emosi menghasilkan vasokontriksi, yang meningkatkan TD dan meningkatkan frekuensi atau kerja jantung.

10. Lakukan terapi relaksasi nafas dalam.

$\mathrm{R} /$ meningkatkan suplai oksigen sehingga nyeri dapat berkurang.

11. Instruksikan pasien dan keluarga mengenai tujuan perawatan dan bagaimana kemajuan akan diukur.

$\mathrm{R} /$ Pengetahuan proses penyakit dan harapan dapat memudahkan ketaatan pada program pengobatan

Berdasarkan tabel di atas didapatkan dari kedua respoden mempunyai rencana tindakan keperawatan yang sama. Tindakan yang dilakukan pada kasus I juga dilakukan pada kasus II.

f. Implementasi keperawatan

Berdasarkan hasil tindakan keperawatan yang dilakukan kepada kedua partisipan merupakan tindakan keseluruhan yang ada untuk penanganaan pasien mengatasi pemenuhan kebutuhan oksigenasi dengan teknik relaksasi nafas dalam.

\section{g. Evaluasi}

Berdasarkan hasil evaluasi yang telah dilakukan, peneliti memiliki keterbatasan waktu untuk mengevaluasi dalam melakukan implementasi keperawatan.

\section{Pembahasan}

Pada pembahasan ini, peneliti akan membahas studi kasus pemenuhan kebuttuhan oksigenasi dengan teknik relaksasi nafas dalam pada kasus Congestive Heart Failure antara Tn. R dan Ny. K di Rumah Sakit Tingkat II Putri Hijau Medan, selama 8 hari. Kasus I mulai dari tanggal 10 Nopember 2016 sampai dengan 13 Nopember 2016 dan kasus ke II mulai dari tanggal 14 Nopember 2016 sampai dengan 17 Nopember 2016 . Dalam hal ini pembahasan yang dimaksud adalah membandingkan antara tinjauan kasus dengan tinjauan pustaka yang disajikan untuk menjawab tujuan khusus dari penelitian. Dimana setiap temuan perbedaan diuraikan dengan konsep dan pembahasan disusun dengan tujuan khusus.
Penelitian melakukan penelitian terhadap dua partisipan yang sama-sama memiliki penyakit Congestive Heart Failure di Rumah Sakit TK II Putri Hijau Medan dengan lima tahap sesuai dengan proses keperawatan yang dikembangkan oleh American Nurse Association (ANA) yaitu pengkajian, diagnosa keperawatan, perencanaan, implementasi, dan evaluasi. Asosiasi Diagnosa Keperawatan America (NANDA) kemudian mengembangkan dan mengelompokkan diagnosa keperawatan serta membantu menciptakan pola komunikasi antara perawat dan dapat memberikan batasan antara diagnosa keperawatan dengan diagnosa medis. Diagnosa keperawatan berfokus pada respons klien, sedangkan diagnosa media berfokus pada proses penakit (Tarwoto,2006)

Tujuan khusus tersebut meliputi menggali pengkajian keperawatan, menyusun perencanaan asuhan keperawatan, merumuskan diagnosa keperawatan, melakukan impplementasi yang komprehensif, serta melakukan evaluasi keperawatan. Berikut ada pembahasan yang disesuaikan dengan tujuan khusus dari penelitian berikut:

4.3.1 Pengkajian

Berdasarkan dari hasil pengkajian kedua partisipan mempunyai diagnosa medis yang sama yang disasarkan pada ketidakmampuan jantung untuk memompakan darah yang adekuat untuk memenuhi kebutuhan jaringan akan oksigen dan nutrisi (Kasron,2016). Jadi Congestive Heart Failure dapat diketahui dengan pemeriksaan radiologi yakni menunjukkan pembesaran jantung. Bayangan mencerminkan ditasi atau hipertrfi bilik atau perubahan dalam pembuluh darah atau peningkatan tekanan pulmonal (Kasron,2016).

Berdasarkan hasil pengkajian kedua partisipan memiliki bebrapa perbedaan yaitu pada kasus I berjenis kelamin laki-laki dan kasus II berjenis kelamin perempuan. Menurut Maudlidta, 2015 menyimpulkan bahwa laki-laki memiliki kecenderungan lebih cepat terkena gagal jantung bila dibandingkan dengan perempuan.6 Hal ini sesuai dengan teori yang mengungkapkan 
bahwa laki-laki memiliki risiko mengalami penyakit jantung koroner 2-3 kali daripada perempuan sebelum menopause.

Kasus I berumur 53 tahun sedangkan pada kasus II berumur 58 tahun. Umur merupakan salah satu faktor risiko yang tidak dapat dimodifikasi. Peningkatan umur akan meningkatkan risiko terjadinya gagal jantung. Hal ini berkaitan dengan proses menua yang menyebabkan peningkatan proses aterosklerosis pada pembuluh darah. Aterosklerosis menyebabkan terganggunya aliran darah ke organ jantung sehingga terjadi ketidakseimbangan antara kebutuhan oksigen miokardium dengan suplay oksigen. Maudidta, 2015.

Pada kedua partisipan megalami nyeri dada dan sesak. Menurut Mutaqqin, 2012 Gejala utama pasien gagal jantung yaitu nyeri dada. Nyeri dada timbul secara mendadak. Penyebabnya yaitu suplai oksigen ke miokardium mengalami penurunan yang berakibat pada kematian sel jantung. Gejala klinis nyeri dada pada kasus gagal jantung, muncul secara tiba-tiba dan secara terus menerus serta tidak mereda. Apabila nyeri ini dibiarkan tingkat keparahan nyeri akan menjadi meningkat sehingga nyeri tidak tertahankan lagi. Nyeri ini disebabkan karena menurunnya curah jantung sehingga suplai oksigen ke miokardium menurun menyebabkan perubahan metabolisme miokardium.

Pada kedua partisipan mengalami riwayat kesehatan yang lalu seperti pada kasus I mengalami riwayat hepatatistis. Menurut Masola (2016) Gagal jantung ditandai oleh ketidakmampuan perfusi sistemik untuk memenuhi kebutuhan metabolisme tubuh dan biasanya disebabkan oleh disfungsi pompa jantung; kadangkadang bisa disertai gejala gangguan nonkardiak seperti gangguan fungsi hati. Hal ini ditandai dengan meningkatnya kadar AST dan ALT yang menjadi patokan untuk abnormalitas fungsi hati. Patofisiologi utama yang terlibat dalam gangguan fungsi hati ialah salah satunya kongestif pasif dari peningkatan tekanan pengisisan atau curah jantung rendah dan akibat dari gangguan perfusi. Gangguan fungsi hati terjadi karena meningkatnya tekanan vena sentralis sehingga mengakibatkan peningkatan enzim hati. Dan kasus 2 mengalami riwayat hipertensi. Menurut Fatoni (2014), hipertensi dapat menyebabkan gagal jantung melalui beberapa mekanisme termasuk hipertrofi ventrikel kiri.Hipertensi Ventrikel kiri dikaitkan dengan disfungsi ventrikel kiri sistolik dan diastolik dan meningkatkan resiko terjadinya infark miokard, serta memudahkan untuk terjadinya aritmia baik itu aritmia atrial maupun ventrikel.Hipertensi merupakan penyakit yang tidak bisa disembuhkan namun dapat dikendalikan atau dikontrol.

Adapun pengkajian kedua partisipan didapatkan yaitu keadaan umum berakral hangat, kesadaran penuh/composmentis dengan GCS 4-5-6, dan posisi klien dalam posisi semi fowler.

Adapun pengkajian kedua partisipan didapatkan yaitu tanda tanda vital mengalami kenaikan sampai pada diatas 140. Menurut Ira (2014) hipertensi didefinisikan sebagai peningkatan tekanan darah sistolik $\geq 140 \mathrm{mmHg}$ dan tekanan darah diastolik $\geq 90 \mathrm{mmHg}$. Hipertensi meningkatkan resistensi ventrikel kiri sehingga beban kerja jantung bertambah. Perjalanan penyakit hipertensi sangat perlahan, kondisi yang kronis dapat mengakibatkan kematian karena payah jantung dan PJK. Deteksi dini dan perawatan hipertensi yang efektif.

Pada pemeriksaan fisik pada Breathing partisipan mengalami peningkatan pada frekuensi pernafasan diatas normal sehingga partisipan mengalami sesak. Menurut jurnal novita (2016) CHF mengakibatkan kegagalan fungsi pulmonal sehingga terjadi penimbunan cairan di alveoli. Hal ini menyebabkan jantung tidak dapat berfungsi dengan maksimal dalam memompa darah. Dampak lain yang muncul adalah perubahan yang terjadi pada otot-otot respiratori.

Pada pemeriksaan fisik pada Bleeding partisipan terdapat suara jantung tambahan (murmur/bising). Menurut Jurnal Lailia (2014) Kegagalan pada jantung kiri memberikan tanda berupa takipnea, rales atau crackles yang mana mengindikasikan telah terjadinya edema pulmonary, perkusi yang redup pada area paru dan penurunan 
suara nafas terutama pada basal paru mengindikasikan telah terjadinya efusi pleura, dan terjadinya sianosis akibat penurunan difusi oksigen pada kapiler pulmonary

\subsubsection{Diagnosa Keperawatan}

Didapatkan kedua pasien yaitu kasus I dan kasus II memiliki diagnosa medis serta diagnosa keperawatan yang sama yaitu CHF dengan diagnosa keperawatan penurunan curah jantung yang dihubungkan dengan kontraktilitas ventrikel kiri menyebabkan peregangan otot jantung sehingga terjadi penurunan curah jantung yang menyebabkan adanya nyeri dada. Nyeri ini disebabkan karena menurunnya curah jantung sehingga suplai oksigen ke miokardium menurun menyebabkan perubahan metabolisme miokardium (Mutaqqin, 2009).

Dimana data yang digunakan dalam menegakkan diagnosa keperawatan lebih difokuskan pada pemeriksaan dan pola pemenuuhan kebutuhan oksigenasi dengan teknik relaksasi nafas dalam kedua responden, dan didapat hasil pada kasus I dan kasus II mempunyai masalah keperawatan yang sama yakni penurunan curah jantung berhubungan dengan dengan kontraktilitas ventrikel kiri menyebabkan peregangan otot jantung sehingga terjadi penurunan curah jantung yang menyebabkan adanya nyeri dada.

\subsubsection{Rencana Keperawatan}

Dari kedua partisipan, kedua mempunyai rencana tindakan keperawatan yang sama dari rumah sakit di ruang rawatan Rumah Sakit TK II Putri Hijau Medan. Rencana tindakan keperawatan di Rumah Sakit TK II Putri Hijau Medan hampir sama dengan rencana tindakan pada teori menurut NICNOC, 2013. Rencana keperawatan tersebut dilakukan sesuai dengan NICNOC dan rawatan Rumah Sakit TK II Putri Hijau Medan.

\subsubsection{Tindakan Keperawatan}

Tindakan keperawatan sama dengan rencana di NICNOC (2013). Tindakan keperawatan yang dilakukan untuk kedua responden sesuai dengan rencana tindakan di
Rumah Sakit TK II Putri Hijau Medan yaitu evaluasi episode nyeri dada (intensitas lokasi, radiasi, durasi, dan faktor yang memicu serta meringankan nyeri dada, monitoring TTV secara rutin, catat tanda dan gejala penurunan curah jantung, monitor status pernapasan terkait dengan adanya gejala gagal jantung, evaluasi perubahan tekanan darah, susun waktu latihan dan istirahat mencegah kelelahan, monitoring toleransi aktivitas pasien, monitor sesak nafas, kelelahan takipnea dan ortopnea, berikan dukungan teknik yang efektif untuk mengurangi stres, lakukan terapi teknik relaksasi nafas dalam, instruksikan pasien dan keluarga mengenai tujuan perawatan dan bagaimana kemajuan akan diukur.

\subsubsection{Evaluasi \\ Pada diagnosa keperawatan} penurunan curah jantung, setelah dilakukan tindakan keperawatan pada tanggal 12 Nopember 2016 s/d 14 Nopember 2016 pada kasus I dan tangggal 29 Nopember 2016 s/d 01 Nopember 2016 pada kasus II. Kedua responden tersebut memiliki respon yang berbeda pada saat dilakuka tindakan keperawatan.

Berdasarkan evaluasi diperoleh hasil yang berbeda antara kedua responden. Pada kasus I didapatkan evaluasi pada hari pertama pada tanggal 12 Nopember 2016 klien masih mengatakan nyeri terasa pada daerah perut kanan bawah bekas operasi, klien mengataka melakukan teknik relaksasi nafas dalam saat nyeri timbul, klien tampak meringis kesakitan, skala nyeri 4 (0-10), klien tampak meringis kesakitan, TTV : TD: 120/80 mmHg, RR:23x/i, HR: 80x/i, T:36,5 ${ }^{\circ} \mathrm{C}$, klien tertidur dalam posisi semi fowler, klien tampak memegangi bekas lukanya, injeksi keterolac diberikan IV $30 \mathrm{mg} / 8 \mathrm{jam}$. Pada evaluasi hari kedua pada kasus 1 tanggal 13 Nopember 2016 klien masih mengatakan nyeri sudah mulai berkurang pada daerah perut kanan bawah bekas operasi, klien mengataka melakukan teknik relaksasi nafas dalam saat nyeri timbul, klien tampak meringis kesakitan, skala nyeri $2(0-$ 10), klien tampak meringis kesakitan, TTV : TD: 120/70 mmHg, RR:22x/i, HR: 80x/i, $\mathrm{T}: 37{ }^{\circ} \mathrm{C}$, klien tertidur dalam posisi semi fowler, klien tampak rileks, klien tampak 
memegangi bekas lukanya, injeksi keterolac diberikan IV $30 \mathrm{mg} / 8$ jam

Dan pada evaluasi hari ke tiga pada kasus I tangaal 14 Nopember 2016 , pasien mengeluh nyeri sudah berkurang, skala nyeri 1(0-10), TTV : TD: $120 / 80 \mathrm{mmHg}$, RR:22x/i, HR: 80x/i, T:36,5 ${ }^{\circ} \mathrm{C}$, klien tampak rileks dan nyaman sehingga masalah nyeri teratasi.

Sementara hasiil evaluasi pada hari pertama pada kasus II tanggal 29 Nopember 2016 paien mengatakan klien mengataka nyeri perut bagian bawah bekas luka operasi, melakukan teknik relaksasi nafas dalam saat nyeri timbul, klien tampak meringis kesakitan, skala nyeri 6 (0-10), klien tampak meringis kesakitan, TTV : TD: $110 / 70$ mmHg, RR:24x/i, HR: 80x/i, T:38,4 ${ }^{\circ} \mathrm{C}$, klien tertidur dalam posisi semi fowler, klien tampak memegangi bekas lukanya, injeksi keterolac diberikan IV $30 \mathrm{mg} / 8$ jam. Evaluasi hari kedua pada kasus II tanggal 30 Nopember 2016 klien mengataka nyeri sudah mulai berkurang perut bagian bawah bekas luka operasi, melakukan teknik relaksasi nafas dalam saat nyeri timbul, klien tampak meringis kesakitan, skala nyeri 4 (010), klien tampak meringis kesakitan, TTV : TD: 110/70 mmHg, RR:24x/i, HR: 80x/i, $\mathrm{T}: 38,4^{\circ} \mathrm{C}$, klien tertidur dalam posisi semi fowler, klien tampak memegangi bekas lukanya, injeksi keterolac diberikan IV 30 $\mathrm{mg} / 8$ jam

Dan pada evaluasi hari ketiga pada kasus II tanggal 01 Nopember 2016 klien mengatakan nyeri berkurang, klien skala nyeri $1(0-10)$, TTV : TD: $110 / 70 \mathrm{mmHg}$, RR:20x/i， HR: 80x/i, T:36,8 ${ }^{\circ} \mathrm{C}$, klien tampak rileks dan nyaman sehingga masalah nyeri teratasi.

Evaluasi yang dilakukan disesuaikan kondisi klien dan fasilitas yang ada, sehingga rencana tindakan dapat dilaksanaan dengan SOAP meliputi subjektif, objektif, analisa data dan planing. Berdasarkan pembahasan tersebut sampai dengan ketergantungantotal sampai dengan ketergantungan sebagian, meskipun proses peningkatan/ pemenuhan itu mengalami perbedaan waktu dari kedua responden. Didalam teori menurut Doengoes (2012) evaluasi tindakan keperawatan pada pasien Appendiktomie dengan nyeri yaitu klien dapat melakukan teknik relaksasi nafas dalam. Untuk itu evaluasi digunakan untuk menentukan apakah masalah tersebut teratasi, teratasi sebagian, atau tidak teratasi. Hal tersebut dibuktikan dengan hasil evaluasi yang telah dilakukan kepada kedua klien yang hasilnya berbeda pada kedua kasus diatas.

Perbedaan perkembangan kedua partisipan dapat disebabkan karena perbedaan koping yang didasari oleh tingkat pendidikan yang dialami oleh klien masing masing walaupun sama -sama masalah teratasi.

\section{KESIMPULAN}

1. Pengkajian

Didapatkan hasil pengkajian dari kedua pasien memiliki beberapa kesamaan yaitu, penyebab dan tanda gejala. Adapun perbedaan antara kedua pasien meliputi umur yang berbeda, tanda - tanda vital yang berbeda, pemeriksaan laboratorium yang berbeda, serta pola pemenuhan nutrisi yang juga berbeda, dan terapi yang diberikan kepada pasien juga berbeda.

2. Diagnosa keperawatan

Berdasarkan dari diagnosa keperawatan didapatkan hasil kedua pasien memiliki diagnosa keperawatan yang sama yaitu gangguan pemenuhan nutrisi yang ditandai dengan kehilangan nafsu makan pada pasien.

3. Rencana tindakan keperawatan

Hasil dari rencana tindakan keperawatan yang telah dilakukan yaitu kedua pasien memiliki rencana tindakan yang sama sesuai dengan SOP rencana tindakan yang ada di rumah sakit meliputi kaji kebiasaan diet, auskultasi bunyi usus, perawatan oral, pemberian periode istirahat, menghindari makanan bergas dan berkarbonat, menghindari makanan yang sangat panas dan sangat dingin, penimbangan berat badan, konsul dengan ahli gizi dalam pemberian makanan, serta pemberian oksigen selama makan.

4. Tindakan keperawatan

Tindakan keperawatan yang dilakukan kepada kedua pasien sama, sesuai dengan rencana tindakan 
keperawatan misalnya dengan pemberian diet yang sama yaitu MB TKTP. Adapun hal yang membedakan yaitu terapi yang didapatkan kedua pasien tidak sama.

5. Evaluasi

Pada hasil evaluasi antara kedua pasien didapatkan hasil yang berbeda. Pada pasien I sudah nafsu makan pada hari ke 2, diet yang diberikan sudah habis 1 porsi, sesak mulai berkurang dan pemberian nasal kanul 2L/i. dan pada hari ke 3 klien tampak lebih segar. Sedangkan pada pasien II keluhan masih belum nafsu makan, diet hanya habis $1 / 4$ porsi sesak masih ada, dan belum ada peningkatan berat badan. Dan pada hari ke 3 perawatan nafsu makan klien sudah ada, diet yang diberikan sudah mampu di habis kan 1 porsi, keluhan sesak mulai berkurang, klien tampak lebih segar dan pemberian nasal kanul 3L/i. Sehingga kedua pasien mengalami peningkatan dalam pemenuhan nutrisi meskipun dalam proses peningkatan tersebut mengalami perbedaan waktu dan tingkat kemampuan.

\section{DAFTAR PUSTAKA}

Brunner and Suddart. 2008. Buku Ajar Keperawatan Medikal Bedah Brunner \& Suddart edisi 8. Jakarta: EGC.

Center for Disease and Prevention. 2015. Heart Failure Fact Sheet. Departemen of Healt and Human Services USA. http://www.cdc.gov/dhdsp/data_statistic/ fac_Sheets/fs_heart_failure.htm

Dinarti, dkk. 2013. Dokumentasi Keperawatan. Jakarta: CV.Trans Info Media

Doengoes, Marilynn E. 2012. Rencanaan Asuhan Keperawatan. Jakarta: EGC

Harigustian, Y. et. all. 2016. "Pengaruh Latihan Otot Inspirasi Terhadap Penurunan Skala Dispnea dan Peningkatan Kapasitas Fungsionak Pada Pasien Gagal Jantung". Indonesian Journal of Nursing Practices. Vol.I No. 1 Desember.

Hidayat, A. 2012. Pengantar Kebutuhan Dasar Manusia. Jakarta: Salemba Medika. https://intensivician.wordpress.com/2016/07 /27/laporan-pendahuluan-congestiveheart-failure-chf/

Kasron. 2016. Buku Ajar Keperawatan Sistem Kardiovaskuler. Jakarta: nuha Medika.

Klabunde, R. E. 2015. Fisiologi Konsep Jantung. Jakarta: Penerbit Buku Kedokteraan EGC.

Kementrian Kesehatan RI. 2014. Situasi Kesehatan Jantung. Pusat Data dan Informasi Kementrian Kesehatan RI.

Loscalzp, J. 2016. Harisson Kardiologi dan Pembuluh Darah. Jakarta: EGC.

Muttaqin, A. 2014. Asuhan Keperawaatan Gangguan Sistem Kardiovaskuler dan Hematologi. Jakarta: Salemba Medika.

Nanda. 2016. Manajemen Keperawatan. Jakarta: CV Trans Info Medika

NIC. 2015. Nursing Intervension Classification. Singapore

Nirmalasari, N. 2016 . "Deep Breathing Exercise Menurunkan Dyspnea pada Pasien Congetive Heart Failure". Nurseline Journal Vol. 2 No. 2 Novenber p-ISSN 2540-7937 e-ISSN 2541-464X.

Rab, T. 2013. Ilmu Penyakit Paru. Jakarta: Trans info media.

Rekam Medis RS TK II Putri Hijau Medan. 2016. RS TK II Putri Hijau Medan.

Setiati, S. 2014. Buku Ajar Ilmu Penyakit Dalam, Edisi 6. Jakarta: Interna Publishing, Jakarta Pusat. 